\title{
The occurrence of mobulid rays at St Helena Island, Cardno seamount and Bonaparte seamount in the South Atlantic and its significance for conservation
}

\author{
Annalea Beard ${ }^{1 *}$, Leeann Henry ${ }^{1}$, Samantha Cherrett $^{2}$ and Alistair D.M. Dove ${ }^{3}$
}

\begin{abstract}
Data from 369 sightings of mobulid rays from St Helena Island, Cardno and Bonaparte seamounts in the South Atlantic are summarised. $50 \%$ (183) of sightings were observed from a boat, $48 \%$ (176) of sightings were encountered in water, of which $95 \%$ (168) were whilst actively scuba diving. $2 \%$ (10) of mobulid ray sightings were observed from land. Sightings data indicate that the Chilean devil ray Mobula tarapacana (Philippi, 1892) is a frequent visitor to St Helena and is present all year. We document the first photographic evidence of the presence of oceanic manta, Mobula birostris (Walbaum, 1792) at St Helena. Two solitary individuals were photographed off the north coast of St Helena in June 2018. These sightings confirm previous unverified reports on the species occurrence and extend the known distribution range of M. birostris in the open South Atlantic Ocean to $16^{\circ} \mathrm{S}$.
\end{abstract}

Keywords: Sighting, range extension, South Atlantic, Mobulidae, St Helena Island, manta ray, devil ray

\section{Introduction}

St Helena is an isolated volcanic island in the South Atlantic, 1200 miles from southern Africa and 1800 miles from South America. St Helena's bathymetry has a rapid drop of in bottom depth resulting in a narrow continental shelf and sea surfaces temperatures range between 19 degrees Celsius (winter) and 25 degrees Celsius (summer) (Brown et al. 2019). In 2016 the 200 nautical mile (nm) Exclusive Economic Zone of St Helena, comprising of $444,916 \mathrm{~km}^{2}$, was designated as a IUCN category VI Marine Protected Area, which includes sustainable use of natural resources (Environmental Management Division 2018). There is expected to be substantial growth in the tourism industry and subsequent increased pressure on the marine environment since the opening of a fully

\footnotetext{
* Correspondence: annaleamichellebeard@yahoo.co.uk

'Marine Section, Environment, Natural Resources and Planning Directorate, St Helena Government, St Helena Island, South Atlantic Ocean, STHL 1 ZZ Jamestown, UK

Full list of author information is available at the end of the article
}

operational airport in October 2017 and establishment of regular commercial flights from South Africa.

Bonaparte Seamount $\left(15^{\circ} 38.40^{\prime} \mathrm{S}, 6^{\circ} 58.20^{\prime} \mathrm{W}\right)$ situated approximately $145 \mathrm{~km}$ west and Cardno seamount $\left(12^{\circ} 54.00^{\prime} \mathrm{S}, 6^{\circ} 03.00^{\prime} \mathrm{W}\right) 330 \mathrm{~km}$ north of St Helena are the only two seamounts regularly used by the local St Helenian offshore commercial fishing fleet and have had no previous records of mobulid rays occurring there.

Mobula tarapacana and M. birostris have a circumglobal distribution, occurring in tropical, subtropical and warm temperate waters. Both species are currently classified as threatened under the IUCN red list (Pardo et al. 2017; Marshall et al. 2011). M. tarapacana were first mentioned occurring at St Helena by Wirtz et al. (2014), however this species has only recently has been formally confirmed (Brown et al. 2019), despite anecdotal records of mobulids occurring as early as 1987 (Edwards et al. 1987; Edwards 1993; Edwards 1990). The closest records of $M$. birostris to St Helena are $1930 \mathrm{~km}$ north west at

(c) The Author(s). 2021 Open Access This article is licensed under a Creative Commons Attribution 4.0 International License, which permits use, sharing, adaptation, distribution and reproduction in any medium or format, as long as you give

appropriate credit to the original author(s) and the source, provide a link to the Creative Commons licence, and indicate if changes were made. The images or other third party material in this article are included in the article's Creative Commons licence, unless indicated otherwise in a credit line to the material. If material is not included in the article's Creative Commons licence and your intended use is not permitted by statutory regulation or exceeds the permitted use, you will need to obtain permission directly from the copyright holder. To view a copy of this licence, visit http://creativecommons.org/licenses/by/4.0/ 
Ascension Island ( $\left.7^{\circ} 57^{\prime} \mathrm{S}, 14^{\circ} 22^{\prime} \mathrm{W}\right)$ (Wirtz et al. 2014), Laje de Santos Marine State Park in south-eastern Brazil (24.150'S; 46 $\left.{ }^{\circ} 100^{\prime} \mathrm{W}\right)$ (Luiz et al. 2009) and along the coast of Ghana, Africa (Essumang 2009; Essumang 2010) (Fig. 1).

\section{Methods}

Details of mobulid sightings were gathered from four sources: (1) A voluntary sightings scheme established in 2003 by St Helena Government for recreational scuba divers, free divers, commercial fishers, recreational fishers, tour operators and members of the public to formally document sightings of marine mega fauna; (2) Historic eyewitness reports gathered from fishers conducting exploratory commercial fishing offshore from $\mathrm{St}$ Helena between 2004 and 2006; (3) Ad hoc sightings recorded by informal fisheries observers placed on commercial fishing vessels operating inshore and offshore from August 2015 to April 2019; (4) Sightings documented by St Helena Government biologists whilst conducting marine research on other species, primarily whale sharks and tuna. In all cases the location and date of the encounter where recorded, and for the reports from fisheries observers and St Helena Government observers behaviours were also noted. Whenever possible, sightings were verified by St Helena Government biologists through face-to-face interviews, videos and inwater still photographs of rays to confirm species identification.
While the reliable identification of smaller mobulids can sometimes be problematic in the field, Mobula tarapacana is quite distinctive among the devil rays. The identification of $M$. tarapacana was confirmed by the sub-terminal mouth, very large size compared to all other devil ray species except $M$. mobular, and the elegantly tapering and falcate wing shape, which is diagnostic of $M$. tarapacana. Throughout the study period, $M$. tarapacana was the only devil ray species reliably identified from eyewitness accounts, photos and videos, except for a handful of records which could only be classed as unidentified mobulids. Identification of the giant oceanic manta ray, Mobula birostris, was confirmed by the extremely large size, which is much bigger than any $M$. tarapacana, the wide terminal mouth, and the presence of roughly triangular white "shoulder patches" on the dorsolateral supra-branchial region, these patches being without "hooks" connecting them to the spiracles as in Mobula alfredi (Marshall et al. 2009).

\section{Results}

369 sightings of mobulid rays were documented between April 1999 and April 2019. 363 sightings were of M. tarapacana consisting of solitary individuals $(67 \%, n=244)$ and schools of up to $14(33 \%, n=119)$. Four sightings were of unidentified mobulid species and two sightings were of oceanic mantas $M$. birostris.

All 70 sightings that occurred at Bonaparte and Cardno seamounts were of M. tarapacana. These encounters were recorded from a boat, either as part of

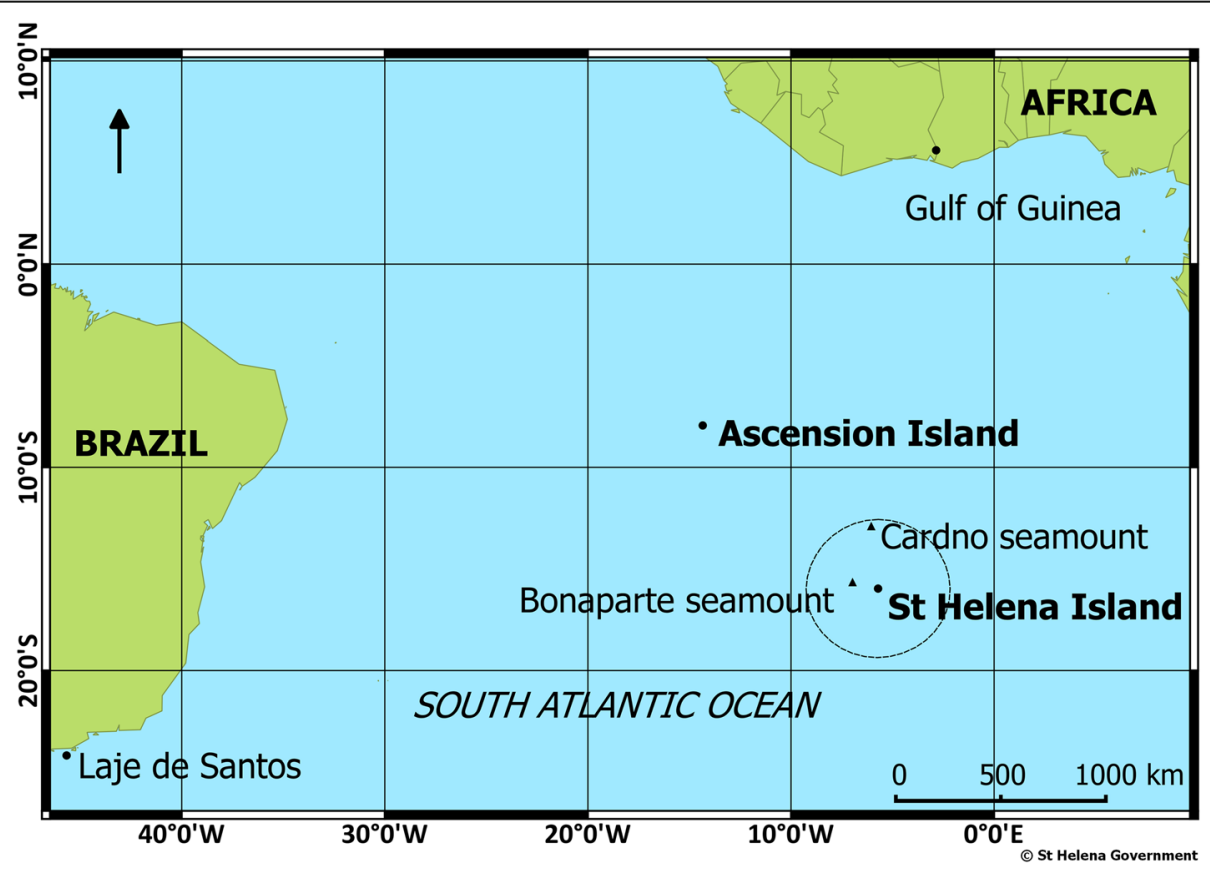

Fig. 1 Map of the South Atlantic Ocean. Dashed line represents the St Helena Marine Protected Area 
commercial fishing activities or during marine research conducted by St Helena Government biologists. Twenty nine of these sightings were recorded between 2015 and 2019 , a period during which $10 \%$ (14 of 142) of all offshore voyages from St Helena were monitored by onboard fisheries observers. These encounters were limited due to the time able to be spent offshore by the vessels. However, data from both inshore and offshore of M. tarapacana shows they are present at St Helena throughout the year (Fig. 2), but with a strong seasonal signal where in animals were more commonly seen in the warmer months. Behaviours reported by observers included cruising, leaping, and feeding both singularly and in groups.

Of the 299 sightings that occurred inshore, $59 \%$ (176) of encounters occurred in water by either swimmers, snorkelers, free divers and scuba divers. Another $38 \%$ (113) were encounters from a boat either as part of commercial, sports or recreational fishing activities as well as wildlife tour operators and recreational boat users. The remaining $3 \%$ (Essumang 2009) of encounters were sightings made from land, shore side or overlooking the sea from cliffs (Fig. 3). Of the in-water encounters, $93 \%$ (168) were whilst actively scuba diving. The frequency of encounters in the sea over the past five years has dramatically increased.

Two different solitary oceanic manta (M. birostris) sightings occurred on two separate days during the study period. The first sighting occurred on the 28th of July, 2018. A solitary oceanic manta ray was seen at the surface, swimming in a north easterly direction $150 \mathrm{~m}$ from the coastline below Ladder Hill Signal House near James Bay. A different solitary oceanic manta ray was seen two days later on the 30th July 2018100 m east of the buoys off Rupert's Bay, from a fishing boat on the north side of the island at the surface. Photographic

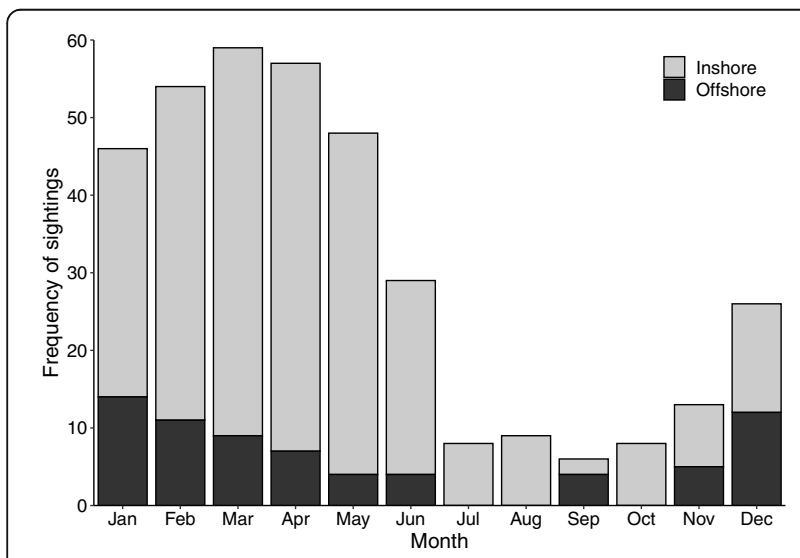

Fig. 2 Frequency of $M$. tarapacana sightings inshore around St Helena's waters and offshore at Cardno and Bonaparte seamount throughout the year recorded between April 1999 and April 2019

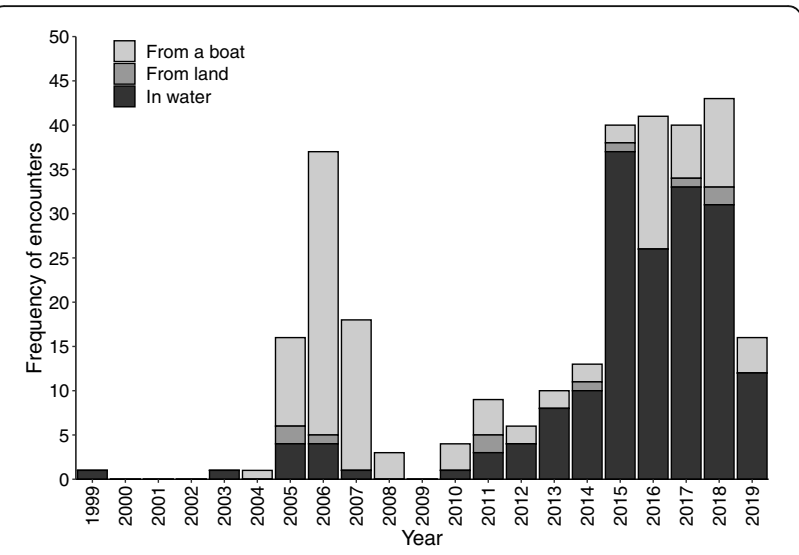

Fig. 3 Yearly mobulid encounters inshore from boats, land and in water

evidence (Fig. 4) confirmed species identification according to the characteristics in Marshall et al. (2009), while differing patterns of white colouration on the pectoral fins indicated that two separate individuals were involved. Cephalic lobes were seen to be unfurled, which might indicate that the animals were feeding.

\section{Discussion}

The increase in mobulid ray sightings recorded in St Helena over the last five years may reflect a real increase in the population of rays visiting or resident at the island, or it may be an artefact of surveillance bias. Encounters of whale sharks (Rhincodon typus) at St Helena also showed similar patterns in recorded sightings (Perry et al. 2020), regardless it provides a starting hypothesis for future dedicated research and/or survey schemes that can account for these different explanations. In particular, the encounters that occur in water may be attributed to an increase in the number of scuba dive tour operators and dive tourists, as well as increased local awareness of marine life and of the St Helena Government sightings scheme. These data highlight the need to monitor mobulid abundance and behaviours and human interactions with these species as marine tourism continues to expand. A Marine Accreditation Scheme has been piloted through the Marine Management Plan (Environmental Management Division 2018) under the Environmental Protection Ordinance (2016) to establish best practice interaction guidelines and offer an incentive for tour operators to achieve high environmental standards. Ensuring these guidelines are fit for purpose and monitoring compliance once the scheme is officially launched will be key to a sustainable tourism industry, species protection and ultimately maintaining the IUCN category VI MPA designation "protected area with sustainable use of natural resources". 


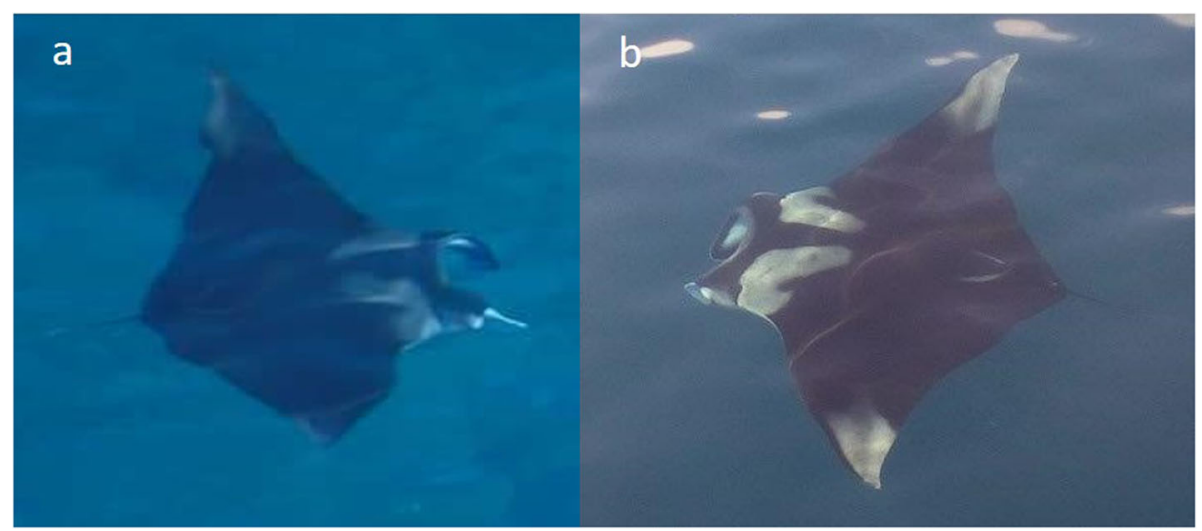

Fig. 4 Photographs of two individual sightings of solitary oceanic mantas M. birostris off St Helena's coastline. Both photos show key characteristics of M. birostris as described in Marshall et al. (2009) notably T shaped black on white coloured shoulder patches on the dorsal supra-branchial region, without "hooks" connecting to the spiracles as in Mobula alfredi. a Encounter recorded 28th July 2018 showing dark dorsal colouration and dark pectoral fins. $\mathbf{b}$ Encounter recorded 30th July 2018 showing chevron shaped marking anterior to dorsal fin; dark colouration around mouth and white colouration on the pectoral fin tips

Few records from commercial fishermen reported mobulids as by-catch however reports were voluntary observations. Accurate accounts of all fishing activities including by-catch as part of improved license regulations and enforcement will increase the accuracy of this estimation. Given all members of the local fishing fleet only use pole and line and there is only one commercial offshore vessel currently in operation, the threats that $\mathrm{St}$ Helenian fisheries pose are low, in contrast to other countries (Couturier et al. 2012; Lawson et al. 2017). While M. birostris is currently not listed as a protected animal under schedule two of the Environmental Protection Ordinance 2016, it would be advantageous to add it at the next revision.

It is not uncommon for $M$. birostris to be sighted around offshore islands, oceanic seamounts and submarine ridge systems (Marshall et al. 2009; Kashiwagi et al. 2011). Mobula tarapacana is also known to be capable of rapid long distance migrations throughout the Atlantic Ocean (Thorrold et al. 2014). Establishing a photo catalogue using, for example, the MantaMatcher platform (WildMe) to identify if the $M$. tarapacana at St Helena are resident and/or migratory would improve management of the marine protected area. Satellite and acoustic telemetry devices may be of some use in identifying habitat use of resident mobulids, but limitations in the current technology are incompatible with the extremely deep diving behaviour displayed by this species (Thorrold et al. 2014) and given St Helena's narrow continental shelf, their use may be problematic as found by Perry et al. (2020) with whale sharks at St Helena. The two sightings of $M$. birostris represent the first time that this species has been confirmed in St Helena and the southernmost record in the open South Atlantic Ocean. These records are important in the characterisation of migration patterns, evaluating the impacts of anthropogenic disturbances, and to advise better resource managers and other stakeholders about effective management practices.

\section{Abbreviations \\ SHG: St Helena Government}

\section{Acknowledgements}

St Helena National Trust (SHNT), St Helena Nature Conservation Group (SNCG), St Helena Dive Club, Dive St Helena, Sub-Tropic Adventures, St Helena Fishermen's Association, Ascension Island Government Conservation Department. SHG marine section staff and volunteers. Staff of the Georgia Aquarium Research and Conservation, Zoological Operations and Dive Operations departments.

\section{Authors' contributions}

AMB conceived, wrote and edited the manuscript, $A D$ assisted with data collection and edited the manuscript, LH and SC assisted with data collection and processing. All authors read and approved the final manuscript

\section{Funding}

Participation of AD was funded by the Research and Conservation program at Georgia Aquarium.

\section{Availability of data and materials}

The datasets used and/or analysed during the current study are available from St Helena Government via the corresponding author on reasonable request.

\section{Declarations}

Ethics approval and consent to participate Not applicable.

\section{Consent for publication}

Not applicable.

\section{Competing interests}

The authors declare that they have no competing interests.

\section{Author details}

${ }^{1}$ Marine Section, Environment, Natural Resources and Planning Directorate, St Helena Government, St Helena Island, South Atlantic Ocean, STHL 1 ZZ 
Jamestown, UK. ${ }^{2}$ Foreign and Commonwealth Office, The Castle, St Helena Island, South Atlantic Ocean, STHL 1ZZ, Jamestown, UK. ${ }^{3}$ Research and Conservation Department, Georgia Aquarium, 225 Baker Street, 30313 Atlanta, GA, USA.

Received: 22 January 2020 Accepted: 23 September 2021

Published online: 15 October 2021

\section{References}

Brown J, Beard A, Clingham E, Frickle R, Henry L, Wirtz P. The fishes of St Helena Island, central Atlantic Ocean - new records and an annotated check-list. Zootaxa. 2019;4543(2):151-94.

Couturier LIE, Marshall AD, Jaine FRA, Kashiwagi T, Pierce SJ, Townsend KA, et al. Biology, ecology and conservation of the Mobulidae. J Fish Biol [Internet]. 2012;80(5):1075-119. Available from: https://onlinelibrary.wiley.com/doi/abs/ https://doi.org/10.1111/j.1095-8649.2012.03264.x.

Edwards AJ, Glass CW. The fishes of Saint Helena Island, South Atlantic Ocean. II. The pelagic fishes. J Nat Hist [Internet]. 1987;21(6):1367-94. Available from: https://doi.org/10.1080/00222938700770871.

Edwards AJ. New records of fishes from the Bonaparte Seamount and Saint Helena Island, South Atlantic. J Nat Hist [Internet]. 1993;27(2):493-503. Available from: https://doi.org/10.1080/00222939300770241.

Edwards AJ. Fish and Fisheries of Saint Helena Island. 1990.

Environmental Management Division SHG. St Helena Marine Management Plan. 2018.

Essumang DK. Analysis and human health risk assessment of arsenic, cadmium, and mercury in Manta birostris (Manta ray) caught along the Ghanaian coastline. Hum Ecol Risk Assess An Int J. 2009;15:985-98.

Essumang DK. First determination of the levels of platinum group metals in Manta birostris (manta ray) caught along the Ghanaian coastline. Bull Environ Contam Toxicol. 2010;84:720-5.

Kashiwagi T, Marshall AD, Bennett MB, Ovenden JR. Habitat segregation and mosaic sympatry of the two species of manta ray in the Indian and Pacific Oceans: Manta alfredi and M. birostris. Mar Biodivers Rec [Internet]. 2011/06/ 10. 2011;4:e53. Available from: https://www.cambridge.org/core/article/habita t-segregation-and-mosaic-sympatry-of-the-two-species-of-manta-ray-in-theindian-and-pacific-oceans-manta-alfredi-and-m-birostris/749771AB4 E18C1E963A5265A502DFD7D

Lawson JM, Fordham SV, Malley MPO, Davidson LNK, Walls RHL, Heupel MR, et al. Sympathy for the devil: a conservation strategy for devil and manta rays. PeerJ. 2017:5:e3027.

Luiz OJ, Balboni AP, Kodja G, Andrade M, Marum H. Seasonal occurrences of Manta birostris (Chondrichthyes: Mobulidae) in southeastern Brazil. Ichthyol Res [Internet]. 2009 Jan;56(1):96-9. Available from: https://doi.org/10.1007/s1 0228-008-0060-3.

Marshall A, Bennett MB, Kodja G, Hinojosa-Alvarez S, Galvan-Magana F, Harding M, Stevens G, Kashiwagi T. Mobula birostris (amended version of 2011 assessment) [Internet]. The IUCN Red List of Threatened Species 2018. 2018 [cited 2019 May 10]. Available from: https://doi.org/10.2305/IUCN.UK.2018-1. RLTS.T198921A126669349.en.

Marshall A, Compagno JV, Bennett L. M. Redescription Of The Genus Manta With Resurrection Of Manta Alfredi (Krefft, 1868) (Chondrichthyes; Myliobatoidei; Mobulidae). Zootaxa. 2009;2301:1-28

Pardo SA, Walls RHL, Bigman JS. Mobula tarapacana (errata version published in 2017). [Internet]. The IUCN Red List of Threatened Species 2016. 2016 [cited 2019 May 10]. Available from: https://www.iucnredlist.org/species/60199/121 705844.

Perry CT, Clingham E, Webb DH, de la Parra R, Pierce SJ, Beard A, et al. St. Helena: An Important Reproductive Habitat for Whale Sharks (Rhincodon typus) in the Central South Atlantic [Internet]. Vol. 7, Frontiers in Marine Science. 2020. p. 899. Available from: https://www.frontiersin.org/article/https://doi.org/10.33 89/fmars.2020.576343.

Thorrold SR, Afonso P, Fontes J, Braun CD, Santos RS, Skomal GB, et al. Extreme diving behaviour in devil rays links surface waters and the deep ocean. Nat Commun [Internet]. 2014;5:1-7. Available from: https://doi.org/10.1038/ ncomms5274.

Wirtz P, Bingeman J, Bingeman J, Fricke R, Hook J, Young T. J. The fishes of Ascension Island, central Atlantic Ocean - New records and an annotated checklist. J Mar Biol Assoc UK. 2014;2014:1-16.

\section{Publisher's Note}

Springer Nature remains neutral with regard to jurisdictional claims in published maps and institutional affiliations.

\section{Ready to submit your research? Choose BMC and benefit from:}

- fast, convenient online submission

- thorough peer review by experienced researchers in your field

- rapid publication on acceptance

- support for research data, including large and complex data types

- gold Open Access which fosters wider collaboration and increased citations

- maximum visibility for your research: over $100 \mathrm{M}$ website views per year

At BMC, research is always in progress.

Learn more biomedcentral.com/submissions 